\title{
UN SÉCULO EN OITENTA ANOS DE VIDA: O CONDE DE PALLARES E A GALICIA DECIMONÓNICA
}

\author{
Por \\ XOSÉ R. VEIGA ALONSO
}

\section{PRESENTACIÓN XERAL E METODOLÓXICA}

Na mañanciñá do 13 de novembro de 1908, o xornal lucense El Norte de Galicia daba conta con grande alarde tipográfico do pasamento en Madrid do vilalbés Manuel Vázquez de Parga, III conde de Pallares. Nos correspondentes e obrigados artigos laudatorios da súa figura, fálase del como "el primero y más autorizado periodista de esta capital y aún de Galicia», como da "alma en las Cortes de aquellas gestiones (...), que precedieron a la solución legal que se ha dado para llegar a la ansiada construcción de la línea férrea de Palencia a La Coruña», sinálanse os seus importantes traballos políticos, en especial a «notabilísima página de su labor parlamentaria (en el tema) de los foros», lóubase a súa «consecuencia política (...) ejemplar» e o seu disfrute dun "poder omnímodo en esta provincia durante la época del mencionado estadista (Cánovas)», e finalmente destácase a súa conversión do "distrito de Villalba en un modelo de distritos en donde no se conocen las venganzas, en donde no existe el caciquismo, en donde los jueces no reciben jamás ni la menor recomendación...», continuando logo o xornal cun abondoso relatorio das innumerables virtudes persoais do finado.

O feito de atopármonos diante dun artigo necrolóxico dotado dunha clara intencionalidade laudatoria, fai que debamos adoptar unha lóxica precaución e un prudente afastamento diante das afirmacións nel recolli-

"CUADERNOS DE ESTUdios GALlEGOS", Tomo XLVII, Fascículo 112, Santiago 2000. 
das. Pero feito isto, e cumprimentado o obrigado tributo á obxectividade histórica e á sempre necesaria crítica da fonte, hai que recoñecer a valía introductoria das liñas contidas do xornal, e isto basicamente por unha razón: permiten recoñecer dunha rápida ollada algúns dos eidos temáticos aos que o Conde adicou unha parte do seu tempo. De certo que as valoracións subxectivas quizais non recollan na súa xusta medida a real importancia histórica do personaxe (quizais non fose o primeiro xornalista do seu tempo nin detentase un poder omnímodo na política provincial), mais iso agora non importa por canto a correspondente pescuda poderá máis adiante situar estes aspectos na súa verdadeira dimensión. Pola contra, si que permiten comezar a fixar algúns aspectos sobranceiros da súa dimensión pública e, deste xeito, ir deliñando os perfís do seu retrato histórico, ao tempo que ofrecen unha dirección cara a que dirixir os esforzos investigadores e mesmo dan pé a facer unha primeira valoración da fondura histórica que presenta unha figura con protagonismo na prensa, a problemática foral, a cuestión ferroviaria e a vida política da Galicia do s. XIX.

A producción historiográfica verbo da Galicia decimonónica a penas se debe algo ás aportacións da biografía histórica. As razóns de tal realidade son moitas e variadas, sen que sexa agora nin o momento nin o lugar axeitados para analizalas, mais sen dúbida que teñen moito que ver co paradigma historiográfico dominante na renovación dos estudios históricos experimentada na universidade do país dende os anos setenta, e que non é outro que o dos potentes Annales saudablemente mesturados con aportacións do materialismo histórico de procedencia francesa e italiana (Domínguez Castro \& Quintana Garrido, 1995, pp. 75-97; Beramendi, 1993, p. 246). Fronte do historicismo de base rankeana, centrado no estudio dos acontecementos políticos e diplomáticos, inxenuamente empirista e defensor absoluto do carácter único e irrepetible (singular) dos feitos históricos, tanto a escola annalista francesa como a historiografía marxista van defender a existencia de regularidades na historia, marxinando o eido ata entón privilexiado dos estudios políticos a prol dunha historia económica e social onde resultaba máis doado aplicar os seus preceptos hermenéuticos e epistemolóxicos, así como sinalar a presencia desas regularidades ata entón negadas e sistematicamente ignoradas (Moradiellos, 1994; Casanova, 1991).

Dentro deste novo contexto historiográfico a biografía histórica quedou por completo desacreditada: se algo podía representar con exactitude

"CUADERNOS DE ESTUDIOS GALLEGOS", Tomo XLVII, Fascículo 112, Santiago 2000. 
as vellas formas de facer historia, desa historia entendida como sucesión de singularidades e feitos irrepetibles onde non cabía ningún tipo de norma nin de xeneralidade, era a biografía (Chaussinand-Nogaret, 1986; Riosa, 1983, pp. 24-28; Dubois, 1992, p. 1.104). Boa parte da responsabilidade neste rexeitamento do biográfico e nesta mala sona do xénero, tiña as súas orixes na propia realidade do traballo con biografías que se viña practicando dende o s. XIX, por canto efectivamente respostaba a unha visión estricta e estreitamente cronolóxica do quefacer historiográfico, dominada polo principio do grande home facedor da historia, do individuo xenial que cos seus actos determina o evoluír das sociedades, que se move sen manter contacto nin recibir influencias do medio que o cingue e que exemplifica na súa irreductible singularidade (e irrepetibilidade) as propias características do acontecer histórico tal e como se entendía antes da renovación propiciada polos Annales. Dende este punto de vista, a reacción fronte da biografía (estensible tamén á historia política que se movía nuns parámetros semellantes) foi non só lóxica senón claramente saudable, un necesario correctivo para un xeito de entender a historia que deixaba fóra dos seus eidos de interese á inmensa maioría da colectividade social en beneficio do estudio exclusivo da actividade duns poucos privilexiados (Seco Serrano, 1976, p. 11).

Sen embargo, a reacción foi demasiado lonxe e estivo mal dirixida nos seus obxectivos. E isto porque, no canto de liberar aos estudios biográficos das eivas e limitacións que presentaban, o que se fixo foi, nun claro exemplo de radicalismo historiográfico, declarar á biografía histórica como un xénero inválido para o estudio, a comprensión e a explicación do pasado, trabucando deste xeito a práctica concreta da biografía (moi criticable nos seus contidos) coa súa validez teórica e metodolóxica como instrumento de pescuda histórica (perfectamente útil cos correspondente axustes e renovacións). Deste xeito, a biografía pasou a considerarse por completo inaxeitada para levar adiante unha práctica historiográfica moderna e científica que era a que dende o materialismo marxista e, sobre todo, dende a historia annalista de Braudel e Le Roy Ladurie se viña defendendo, do mesmo xeito que ocorriu coa análise da dimensión política das sociedades por completo ausente na producción da dominante escola francesa (Pillorget, 1985, pp. 82 e ss.; Le Goff, 1995, pp. 157, 161; Stone, 1982).

A chamada moda dos retornos que afecta á historiografía da segunda metade dos anos 80 e da década dos 90 , ten no revival da biografía histó- 
rica un compoñente fundamental. Sen entrar agora nas múltiples e moi variadas causas que se sitúen na orixe desta recuperación ${ }^{1}$, si convén deixar claro que recuperación non significa necesariamente renovación, del tal xeito que moita da inxente producción biográfica dos últimos anos en absoluto se afasta dos modelos clásicos que foran tan xustamente criticados anos atrás (Piqueras, 1994, p. 60), polo que aínda hoxe é perfectamente válido o duro dictame que o historiador francés J. Le Goff facía en 1989 verbo deste retorno do biográfico:

"Ce qui me désole dans l'actuelle prolifération de biographies, c'est que beaucoup sont de purs et simples retours à la biographie traditionnelle, superficielle, anecdotique, platement chronologique...» (Le Goff, 1989, pp. 49-50).

A mensaxe que enviaba Le Goff era clara: tentar un simple rexuvenecemento superficial do xénero non serviría de nada se as bases que o sustentan seguen a ser as mesmas de hai cen anos. Xa que logo, o que cómpre facer é algo moi diferente: recuperar renovando e aplicando á biografía os múltiples avances habidos na historiografía a partires da II Guerra Mundial. Deste xeito, hai que esquecer a idea do individuo xenial que se explica a si mesmo e que resume e representa na súa traxectoria toda a densidade histórica dunha determinada época, a prol doutra visión que explique ao suxeito no seu contexto e como froito dese contexto, como resultado da interacción de múltiples variables (políticas, sociais, económicas, ideolóxicas, culturais) que rematan por configurar unha determinada personalidade. Igualmente, hai que matizar a visión do individuo clarividente, adiantado á súa época e incomprendido na súa xenialidade polos contemporáneos, para buscar a súa integración en grupos máis amplos dos que sen dúbida forma parte e cos que comparte semellanzas e preocupacións: é o traballo prosopográfico que ultimamente ten dado tan bos froitos no eido da historia política ${ }^{2}$.

\footnotetext{
${ }^{1}$ Le Goff (1989, 1995), Morales Moya (1993), Romano (1983), Sgambati (1995), Veiga $(1995,1995-96 b)$.

${ }^{2}$ Por exemplo, o excelente estudio coordenado por Carasa Soto (1997) ou o encabezado por Agirreazkuenaga (1993).
}

"CUADERNOS DE ESTUDIOS GALLEGOS", Tomo XLVII, Fascículo 112, Santiago 2000. 
Unha terceira coordenada a considerar nesta renovación do biográfico, debe dirixirse a evitar caer na biografía centrípeta que reduce o interese da análise á pura individualidade e que esquece as dimensións externas ao individuo que están a condicionar a súa actuación. Este tipo de estudios rematan sempre por resultar inutis: nin explican as razóns forxadoras desa individualidade nin, o que é pior, aportan nada ao coñecemento e comprensión do período histórico no que está enmarcada. Pola contra, a opción a considerar é a contraria, a da biografía centrífuga que, a partires do suxeito concreto, tenta achegarse a algúns dos problemas históricos que definiron a súa época. Así, hai que tentar trascender a figura do biografiado e a súa problemática estrictamente individual a prol dunha visión que privilexie as cuestións de conxunto nas que está interesada a colectividade, pero facéndoo sempre coa idea clara de que se está a realizar un traballo biográfico con todo o que isto supón de seguemento dunha traxectoria vital concreta, debedora do contexto histórico ao que pertence pero tamén ela mesma forxadora en maior ou menor medida (ben sexa como arquitecto director, ben como simple pión de obra) dese mesmo contexto que a inclúe. En suma, o resultado a perseguir por toda boa biografía é resolver atinadamente a permanente tensión dialéctica que se establece entre suxeito e obxecto, entre individuo e colectivo/clase, buscando ese punto de equilibrio entre o xeral e o particular tan difícil de acadar nos traballos biográficos (Pereyra, 1984). Este precisamente será o obxectivo das páxinas que seguen adicadas ao conde de Pallares e á Galicia na que desenvolveu o seu protagonismo.

\section{A PRENSA COMO DEFENSORA DE PROXECTOS SOCIOECO- NÓMICOS E POLÍTICOS}

Manuel Vázquez de Parga Somoza y Pallares ven ao mundo no lugar de Penascorbeiras, parroquia de Sancobade, xurisdicción de Vilalba, o 13 de San Xoán de 1828. Nace no seo dunha familia de tradición fidalga que sitúa as súas orixes no primeiro tercio do s. XVIII cando D. Bernardo Vázquez de Parga obtén para a liñaxe o recoñecemento de fidalguía, transmitíndoo logo a D. Ramón Vázquez de Parga e este á súa vez a D. Antonio Vázquez de Parga, avó e pai, respectivamente, do biografiado. Pola banda da súa nai, $D^{a}$ Manuela Somoza y Pallares, os alicerces sociais son os 
mesmos: filla de D. Francisco Somoza y Somoza Vizcaíno e de Da Ángela Somoza y Pallares, aparécesenos como herdeira das casas do Hospital do Incio e de Rivas Pequenas en Bóveda ${ }^{3}$. Xa que logo, as orixes sitúano como integrante da elite dirixente do país en canto membro do grupo dominante na Galicia antigorreximental, desa fidalguía que tiña na percepción de rendas e no desempeño de funcións burocráticas dentro da administración absolutista as súas sólidas bases de sostén económico, prestixio social e influencia política: D. Antonio Vázquez de Parga, pai de Manuel, en canto perceptor de rendas nas zonas de Lugo capital e Vilalba, subdelegado de facenda na provincia e deputado por Lugo nas Cortes gaditanas, personifica á perfección a este grupo privilexiado 4 .

O xove Manuel ve como morre seu pai cando contaba con a penas 4 anos de idade, un feito que sen dúbida marca toda a súa inmediata traxectoria posterior ao quedar como o único varón da familia e, como tal, responsable directo de perpetuar os apelidos e o bo nome da liñaxe, unha circunstancia a ter moi presente á hora de explicármonos a precocidade que preside moitas das súas actuacións e que sen dúbida hai que relacionar con esta necesidade de asumir responsabilidades con prontitude e de cargar dende moi cedo co peso da tradición familiar. Logo duns primeiros estudios no Seminario Conciliar da cidade das murallas, obtén o bacharel en Xurisprudencia pola universidade de Salamanca en 1848, para completar a licenciatura de Dereito Civil e Canónico na de Valladolid en 1852 non sen antes ter pasado tamén pola de Santiago no curso 1849$50^{5}$. A traxectoria exemplifica á perfección un cursus honorum que atopa numerosos correlatos no de moitos outros vástagos de familias poderosas (os mesmos antergos de Manuel tamén seguiran a carreira de leis), que elixen igualmente o camiño da licenciatura en Dereito como o me-

\footnotetext{
${ }^{3}$ Datos tomados do arquivo privado de Manuel J. Platero Campo. Aproveito agora para reiterarlle o meu agradecemento pola súa xenerosidade intelectual e humana.

${ }^{4}$ Arquivo Histórico Provincial de Lugo (en adiante, AHPL), serie Xeral, documentación do Conde de Pallares (en adiante, CP), leg. 1; Museo Provincial de Lugo (en adiante, MPL), fondo «Pleito del diezmo de patatas. Escudos. Foros»; MPL, fondo «Sr. Conde de Pallares».

${ }^{5}$ Expedientes persoais de D. Manuel Vázquez de Parga: Archivo Universitario de Valladolid (leg. 677-41) e Arquivo Histórico Universitario de Santiago (sección Expedientes Personais, leg. 1.539).
}

"CUADERNOS DE ESTUDIOS GALLEGOS", Tomo XLVII, Fascículo 112, Santiago 2000. 
dio ideal para facer carreira política e para poder moverse con desenvoltura e facilidade no mesto marco xurídico con que aos poucos se ía dotando o aínda xove Estado liberal: nunha sociedade semianalfabeta e por completo allea aos misterios da lexislación, o coñecemento dos códigos xurídicos era unha fonte certa de poder e influencia sociais (Bahamonde \& Martínez, 1994, p. 470; Siegrist, 1989, 1992; Banti, 1996, pp. 104-120).

Pero a universidade non só aporta coñecementos e títulos senón tamén novos coñecidos, novas relacións e, o que agora máis nos importa, os primeiros contactos coa prensa. O selecto e restrinxido ambiente da universidade decimonónica proporciona o contexto axeitado no que as futuras clases dirixentes traban contacto entre elas, forxan sólidas ligazóns de amizade e compañeirismo, desenvolven os primeiros proxectos en común e solidifican aínda máis as xa de por si ben definidas solidariedades clasistas: en resumo, aparece como o escenario onde se vai construíndo unha elite de discurso máis ou menos variado pero sempre vencellada por sólidos intereses comúns que saben defender solidariamente nos momentos oportunos. Así, e repasando a correspondencia dos anos universitarios de Vázquez de Parga, atopámonos con apelidos que no decorrer do tempo xogarán un papel salientable na súa actividade política: os Rebellón e os Noguerol de Viveiro, os lucenses Pardo Domínguez e Pardo Valcárcel, o coruñés Vicente P. Calderón (futuro conde de San Juan), o ferrolán PardoBazán, os ponteareáns Bugallal..., son algúns dos que se repiten nas misivas $^{6}$. Sen dúbida que un destes espacios de construcción dos que falabamos é o que constitúe a prensa, foro obrigado para calquera xove inquedo e disposto a chegar lonxe no mundo da política (Seoane, 1983). Manuel comeza a rendir o obrigado tributo á letra impresa dende moi cedo, de tal xeito que Pérez Constanti (1905, p. 125) atopa xa colaboracións súas no xornal de orientación liberal El Correo Salmantino datadas na segunda metade dos anos 40. Pero realmente vai ser ao longo da breve estadía na universidade compostelá cando desenvolva a súa primeira empresa xornalística seria, importante nun dobre sentido: porque supón a presentación en sociedade de Vázquez de Parga integrando unha iniciativa de evidente proxección social (neste sentido, é o primeiro paso na súa andaina como persoeiro público), e tamén porque permite coñecer os intereses e inquedanzas que animaban ao estudiantado santiagués nos anos en que mediaba o século.

"CUADERNOS DE ESTUDIOS GALLEGOS", Tomo XLVII, Fascículo 112, Santiago 2000. 
A Revista de Galicia (1850) é o froito, precoz e inmaduro, dos afáns, as ilusións e as esperanzas dun grupo de mozos cheos de vitalidade e desexosos de facer a súa particular aportación á necesaria rexeneración galega $^{7}$. Dirixida por un xovencísimo Vázquez de Parga (22 anos), intégrase á perfección dentro do ambiente cultural do Santiago que atravesa o ecuador do século e supón un elo máis dentro da longa cadea de publicacións semellantes que ven a luz na cidade compostelá, ao tempo que reflicte sen distorsións o espíritu pragmático e positivista que preside a prensa (de intereses morales y materiales) de todo o Estado logo da fin das guerras carlistas (Molina, 1989; Lorenzana, 1988; Pérez Pais, 1974?; Villanueva Herrero, 1988; Seoane, 1983). Pero ademais desta correspondencia externa, a publicación é un perfecto mostrario da propia evolución persoal do xove Manuel que do mundo adolescente e xuvenil dominado pola poesía, os amores apaixoados e os dispendios xenerosos que se deixa ver nas correspondencias universitarias ${ }^{8}$, dá o paso cara un universo xa adulto no que comeza a asumir as responsabilidades públicas que se derivan da súa orixe, formación e categoría social, un novo contexto no que a análise desapaixoada da realidade, o pragmatismo e o utilitarismo ocupan o espacio antes reservado á ensoñación e á imaxinación. En suma, Vázquez de Parga inicia coa Revista o proceso que o levará a formar parte da intelligentsia pensante do país, ao tempo que lle serve para facer a súa primeira aparición pública como integrante da informal consciencia colectiva da sociedade galega.

A iniciativa, feble e precipitada de mais, carente de calquera apoio financieiro que non sexa o procedente dos propios redactores, de só morna recepción nos ámbitos oficiais e demasiado dependente do sempre escaso tempu que lle poden adicar os seus promotores, ten unha vida curta $\mathrm{e}$ pouco exitosa en lectores, reflectindo tamén nisto unha característica xeneralizable a moitos outros proxectos xornalísticos deses anos que como mellor (e case único) aval contan co entusiasmo dos seus impulsores 9 .

\footnotetext{
${ }^{6}$ As correspondencias pódense consultar no MPL, fondo «Sr. Conde de Pallares».

${ }^{7}$ Ademais de Vázquez de Parga, integraban a redacción José Pardo-Bazán, Antonio de la Iglesia, José Ma Gil, Tomás Martínez Servida e Germán Castro Arias.

${ }^{8} \mathrm{MPL}$, fondo «Sr. Conde de Pallares».

${ }^{9}$ Cartas de J. M ${ }^{\text {a }}$ Gil a V. de Parga, 12-VII e 18-VIII-1850, MPL, fondo «Sr. Conde de Pallares»; Revista de Galicia, 1 e 15-VII-1850; El Norte de Galicia, 13-XI-1908.
} 
Pero antes de desaparecer, a publicación ten tempo de saír á rúa nunha ducia de ocasións (se ben só puidemos consultar seis entregas) e de amosar con claridade os seus obxectivos, os eidos temáticos polos que se interesa e tamén as súas limitacións. A Revista, aínda que o faga dun xeito indirecto e carente de calquera intencionalidade política, recolle os ecos do movemento provincialista nado na cidade compostelá e sitúa a Galicia, ao seu coñecemento e á súa presentación en positivo superando tópicos inxustos, no centro dos seus esforzos divulgadores. A meta que se fixan Vázquez de Parga e os seus compañeiros está clara: situar ao país na onda modernizadora que percorre Europa rematando co descoñecemento en forma de menosprezo que recae sobre del, empregando a prensa tanto para superar a falsa (e negativa) imaxe exterior de Galicia como para espallar aquelas melloras que poidan resultar proveitosas para o seu desenvolvemento. Como expresa o propio Vázquez de Parga, ser de utilidad, principal tendencia de la época. Deste xeito, a problemática agraria (instrucción agrícola, temática forestal, cuestión foral), o estudio xeográfico do país ou a reflexión sobre a realidade educativa ocupan as páxinas da publicación, empeñada nunha imposible laboura divulgadora e culturizadora posta ao servicio da promoción material e espiritual do solar patrio.

A segunda iniciativa xornalística do xa conde de Pallares (recibe o título en 1857) dátase en 1860, e como ocorrera coa Revista xurde ao abeiro dun novo proxecto que ten a Galicia e ao seu desenvolvemento como destino final. El Correo de Lugo (CL), que así se chama a publicación, presenta sen embargo importantes diferencias verbo da anterior, marcándose tamén deste xeito as distancias que separan ao mozo Manuel de 1850 do conde de Pallares de 1860 casado, con fillos e xa unha vez representante en Cortes do distrito de Lugo capital. O Correo comparte coa súa antecesora o principio ideal da prensa posta ao servicio dunha causa entendida como boa e positiva para a colectividade e, xa que logo, ambas as dúas teiman en considerar ao medio escrito como instrumento axeitado na defensa de iniciativas de progreso para Galicia, pero as semellanzas entre as publicacións rematan aquí. Así, toda a improvisación, a falla de madureza, a precipitación e a escaseza de apoios que definían á Revista, desaparecen agora a prol dun proxecto máis serio, con obxectivos concretos ben definidos e cunha nómina de colaboradores (cuantitativa e cualitativamente) nu- 
merosa ${ }^{10}$, circunstancias que, non obstante, tampouco impedirán que teña unha vida tan breve como a da súa predecesora compostelá (publícase entre maio de 1860 e febreiro de 1861).

O xornal recolle á perfección os temas de maior interese que se axitaban na Galicia de 1860, unha temática que o propio rotativo contribúe a enriquecer de xeito decisivo e que reflicte sen a penas deformacións as teimas particulares do conde de Pallares, situación lóxica nunha época en que os proxectos de dimensión pública resultaban case sempre debedores de iniciativas promovidas por ben marcados persoeiros integrados nos reducidos e selectos círculos das elites locais. Seguindo a clasificación que dos xornais de provincias fai J. F. Botrel (1992), ao Correo deberiamos consideralo como unha iniciativa que nace co obxectivo claro de apoiar un proxecto económico determinado, en concreto o tendido dunha vía férrea entre Palencia e A Coruña que asegure a conexión de Galicia coa rede estatal e remate dunha vez co máis que secular illamento terrestre do país (Abel Vilela, 1981, p. 152; Carré Aldao, 1991, p. 262; Veiga, 1995-96a, 1996, 1998a). Dende o número inicial a presencia de novas relacionadas co proxectado ferrocarril é unha constante que se repite ata que a publicación deixa de existir coincidindo coa subhasta dos tramos castellanos da liña (febreiro de 1861), exercendo unha constante laboura publicitaria a prol do camiño de ferro: fai públicas todas cantas novidades se producen relativas á empresa, anima a suscrición de accións, rebate os argumentos contrarios ao proxecto que van xurdindo, relaciona os innumerables beneficios que acompañarán a chegada do ferrocarril... Pero na mente do Conde o tren non viaxa só, conscente como é de que só cunha fonda transformación das estructuras productivas poderá o país aproveitarse das ventaxas que trae aparelladas o camiño férreo $(C L, 20-\mathrm{V}-1860)$.

\footnotetext{
${ }^{10}$ Entre eles, o avogado e pensador agrario José $\mathrm{M}^{\mathrm{a}}$ Castro Bolaño, os médicos Dimas Corral e José J. de la Peña, os tamén avogados Nicandro García Taboada e Manuel Pardo Domínguez, o comerciante Pedro Pozzi e os funcionarios Nicolás Pardo Pimentel e Teolindo $\mathrm{M}^{\mathrm{a}}$ Romero, todos integrantes da elite pensante do Lugo deses anos, algúns con libros e folletos publicados (Bolaño, de la Peña), varios con experiencia no xornalismo de provincias (Pallares, Pimentel, Bolañog, Corral, Romero e Pozzi, os catro últimos redactores de La Aurora del Miño, rotativo que vira a luz na cidade amurallada no ano 1857) e a maioría con presencia nos órganos político-administrativos da cidade (Pallares, Bolaño, Pozzi, Taboada e Pimentel no Concello e a Deputación; Pallares e Bolaño na Xunta de Agricultura; Corral na de Beneficencia; de la Peña na de Instrucción Primaria).
} 
Así, o Correo dá cabida nas súas páxinas a unha fonda discusión respecto da problemática foral, referencia case monotemática dos pensadores galegos decimonónicos e auténtica cerna arredor da que xiran todos cantos proxectos de cambio circulan na época con referencia ao agro galego. Para Pallares está clara a necesidade de reordenar en sentido capitalista a estructura da propiedade como único xeito de que as vías férreas poidan servir de eficaz mecanismo integrador no mercado da producción galega, e de aí o ofrecemento do xornal como tribuna aberta a todos cantos pensadores teñan algo que dicir no tema, chamada á que resposta Castro Bolaño en sentido redencionista pero que tamén aproveitan Amor Labrada, Sancho Gutiérrez e J. Gil para manifestar a súa postura contraria (aínda que moi matizada no caso de Gutiérrez) a esta solución. A pluralidade de opinións amosa as diferentes sensibilidades e os moitos intereses que rodean á cuestión foral, ata o punto de que o propio Correo recoñece que nin sequera a redacción mantén neste tema unha postura común $(C L, 25$-IX1860).

As colaboracións que vimos de reseñar convirten ao xornal lugués nun foro privilexiado onde teñen cabida as encontradas posicións que anos despois explicitaranse con rotundidade no Congreso Agrícola de 1864 (Villares, 1994). Fóra do asunto foral, as reflexións no eido agrario diríxense cara á necesidade de dar un pulo ao espíritu de asociación campesiño, de fomentar a cultura forestal entre os labregos ou de frear a suba que están a experimentar os xornais agrícolas, completándose o corpus redaccional do Correo con artigos referentes á beneficencia pública (tema moi de actualidade na época polo temor que espertaba a pantasma do pauperismo), á necesidade de crear na provincia institucións de crédito e con reflexións respecto da importancia dunha educación integral, socializadora e civilizadora baseada en sólidos principios cristiáns. O repaso feito permite definir á publicación dirixida por Pallares como producto típico do seu tempo, como unha iniciativa que non só recolle inquedanzas e esperanzas propias do Conde senón que dá acubillo nas súas páxinas a unha ampla temática representativa dalgúns dos asuntos máis de actualidade no panorama galego e estatal. Afastado de calquera intencionalidade política (cando menos explícita), e como xornal adicado á promoción dos intereses morales y materiales, actúa na mesma lonxitude de onda ca Revista buscando servir de vehículo transmisor das iniciativas de progreso que, chegadas de Europa, estar a ter recepción na Península e que se des- 
exa arriben tamén ao lonxano fisterre galaico. Superadas as liortas civís coa derrota do carlismo, e acadado un mínimo consenso institucional entre as forzas políticas, ten chegado a hora de instalar ao país no carro das melloras materiais que no continente conducen a Inglaterra victoriana e a Francia imperial de Napoleón III: nada mellor para logralo que superando o illamento galego co tendido das vías férreas e rematando coa propiedade de reminiscencias feudais substituíndo ao foro por outras fórmulas de cesión máis xenuinamente capitalistas, ambiciosos obxectivos que teñen no xornalismo, símbolo dos novos tempos, o mellor dos aliados (Durán de la Rúa, 1979; Romero-Balmas, 1982a, 1982b; Fontana, 1973; Ringrose, 1996; Barreiro Fernández, 1986; Saurín de la Iglesia, 1977).

A terceira das empresas xornalísticas do Conde que imos a considerar afástase dabondo dos dous exemplos xa presentados, e de novo a toma en consideración das obrigas derivadas do contexto resulta imprescindible para comprendermos as razóns deste novo proxecto. Así, e fronte do apoliticismo da Revista e o Correo que atopa xustificación tanto no dominio político que por entón exercen opcións moderadas que non poñen en cuestionamento os intereses dos grupos sociais dominantes nos que Pallares se integra (e que, xa que logo, non precisan de medios públicos que defendan a súa privilexiada posición), como no propio ambiente social que semella demandar antes progresos económicos que cambios políticos, o caso de El Eco de Galicia (Lugo, 1872-75) é o dunha publicación de obxectivos marcadamente políticos que aparece como resposta ao cuestionamento (real ou aparente, que iso agora pouco importa) que as políticas do Sexenio Democrático plantexan a varios dos eixos de flotación en que se sustenta o control que a oligarquía de base (fundamental, aínda que non unicamente) agraria viña exercendo no Estado: dinastía borbónica/monarquía, incuestionable propiedade privada, catolicismo oficial e excluínte, fiscalidade regresiva, actividade política restrinxida (sufraxio censitario), unidade nacional... (Piqueras, 1992; López Cordón, 1976). Deste xeito, a actividade do Eco dende a súa aparición en agosto de 1872 resúmese nunha constante e teimuda laboura de oposición fronte de toda a obra do Sexenio, actividade de zapa que complementa coa presentación da súa opción restauradora e coa defensa dos bens e facendas daqueles colectivos (singularmente, propietarios agrarios) que comezaban a prestar auxilio á causa alfonsista, cumprindo así coas tres funcións básicas de todo 
xornal de oposición: atacar ao executivo gobernante, publicitar a propia alternativa e ofrecer acubillo e protección aos mancados intereses dos seus apoios sociais. Se agora repasamos as páxinas do rotativo dirixido por Pallares, vemos que cumpre axeitadamente os obxectivos asignados coa súa descalificación dos gobernos do Sexenio por ilexítimos, anárquicos e demagogos, co seu intento de gañar novos prosélitos para a causa entre as masas católicas do país (moi traballadas polo carlismo, rival directo dos alfonsistas neste eido pola súa cerrada defensa dos privilexios da igrexa), coa súa presentación do alfonsismo como opción política nacional, cívica e incluínte de todos os grupos que acepten a restauración na figura de Alfonso XII (daí a oposición a toda solución secesionista en Cuba, a crítica sen paliativos do cantonalismo ou o rexeitamento a unha volta dos borbóns apoiada nos sables dos militares, principio máis teórico ca real como os acontecementos se encargaron rapidamente de demostrar), e coa defensa que realiza dos perceptores de rendas forais que vían como a lei de redención republicana (agosto de 1873) puña en perigo o piar fundamental das súas economías. Como se comproba doadamente, estamos na presencia dun emprego do xornalismo ben afastado dos ideais plantexamentos colectivos defendidos na Revista e o Correo, primando agora, nun contexto de evidente exacerbación dos plantexamentos ideolóxicos, a defensa dos intereses de clase daqueles colectivos (propietarios, rendistas, eclesiásticos, industriais, militares) que se consideraban ameazados polas reformas democráticas, rematando así por definir un emprego cambiante e variable da prensa por parte do conde de Pallares, sempre moi atento ás necesidades do momento e a cumprir coas obrigas impostas polo contexto.

\section{AGRICULTURA E VÍAS FÉRREAS: OS ALICERCES DO DESENVOLVEMENTO GALEGO}

Para calquera pensador minimamente atento á realidade galega do $\mathrm{s}$. XIX, resultaba evidente que a potenciación das posibilidades agrogandeiras do país era o eixo básico arredor do que debía xirar calquera proposta tendente á modernización das súas estructuras productivas, esquema conceptual do que o conde de Pallares participaba totalmente. A súa actuación neste eido agrario resulta de interese por un dobre motivo. Por unha 
banda está a súa faceta de pensador e ensaísta ${ }^{11}$, que permite integralo con pleno dereito na nómina dos agrónomos de salón que ten estudiado Fernández Prieto (1992), pero pola outra debemos referírmonos ao seu activismo como lexislador en materia foral, como agricultor a la moderna $\mathrm{e}$ como integrante e director de exposicións agrícolas, vertente práctica que serve de complemento ás súas preocupacións teóricas e que é máis difícil de atopar entre os seus compañeiros de xeración.

Como case non podía ser doutra maneira, Pallares participa do pensamento de raíz fisiocrática que sitúa á agricultura como a base imprescindible de toda actividade productiva, unha ideoloxía fondamente agrarista que ademais aparece adubada con certos toques antiurbáns e antiindustriais. Do mesmo xeito, e compartindo esta característica cos restantes pensadores agrarios do momento (tanto de Galicia como de fóra dela), o arbitrismo domina por enteiro o seu discurso, cunha marcada tendencia a aportar posibles solucións aos problemas que vai atopando no seu repaso da realidade agraria do país. En contra do que poden suxerir os títulos da Memoria e o Informe, non é a preocupación polo ensino agrario (e, en consecuencia, pola falla de formación agronómica entre os labregos) a que se sitúa no cumio da morea de eivas e atrancos que se opoñen en Galicia ao desenvolvemento dunha actividade agrícola plenamente capitalista. Pola contra, Pallares deixa claro que tal primacía correspóndelle por enteiro á deficiente estructura que presenta a propiedade territorial, legalmente organizada a partires do sistema foral e fisicamente definida

"Informe presentado a la Junta de Agricultura de la provincia de Lugo por su vicepresidente el Conde de Pallares en contestación al interrogatorio sobre el estado de la enseñanza agrícola, sobre los medios de contribuir a su propagación y al fomento de la agricultura, dirigido en 10 de Mayo de 1862, por el Excmo. Sr. Ministro de Fomento, Lugo, 1862; Memoria sobre la necesidad de establecer escuelas de Agricultura en Galicia (Madrid, 1862; en colaboración con José Pardo-Bazán, responsable principal do traballo); «Estado de la propiedad en Galicia», La Época, 25 e 28-IX, 5-X, 10-XI e 12-XII1866; Memoria y Catálogo de la Exposición agrícola y de ganados celebrada en Lugo en Octubre de 1867, formada según encargo de la Diputación Provincial por el Conde de Pallares... (inédita e sen paxinación; conservada no Museo Provincial de Lugo, fondo «La Exposición Agrícola y de Ganados celebrada en Lugo. Octubre de 1867»); artigos varios publicados no xornal El Eco de Galicia entre 1872 e 1874. Agás indicación expresa en contrario, os comentarios verbo dos puntos principais do seu pensamento agrario proceden daquí.

"CUADERNOS DE ESTUDIOS GALLEGOS", Tomo XLVII, Fascículo 112, Santiago 2000. 
por unha esaxerada división do terrádego xeradora dunha infinidade de pequenas parcelas, estremo parcelamento que ten no foro (polas amplas posibilidades de xestión e organización da terra que concede aos utis cultivadores) unha das causas principais. Esta situación estructural é, na mente do Conde, responsable directa das dificultades que presenta en Galicia a adopción de prácticas agrícolas modernas: impide a fixación de rotacións de cultivo completas, dificulta a experimentación con novas plantas, forza a manter en vigor as prácticas colectivas, imposibilita o emprego de maquinaria, crea numerosos lindeiros que ocupan terreo susceptible de cultivo, provoca grandes perdas de tempo nos desprazamentos dunha leira a outra..., ademais de cargar aos cultivadores cunha pensión perpetua e irredimible (o foro) que non fai senón empiorar a situación das xa de por si maltreitas economías labregas. Feito o diagnóstico da enfermidade, as solucións a adoptar aparecen claras no pensamento de Pallares: fomento das reuniones territoriales na liña do que viña sucedendo en Europa e redención foral, únicos remedios que serán quen de acadar explotacións das dimensións axeitadas e de rematar coa dualidade de dereitos sobre a terra.

Só logo de solucionados estes problemas centrais plantexa o Conde a seguinte das eivas a superar centrada na ignorancia que preside moitas das prácticas labregas, pois de non seguirse esta orde de prioridades «la enseñanza agrícola ofrecerá el mismo resultado que las lecciones dadas sobre el uso de la libertad a los confinados a cadena perpetua» (Informe, p. 116) ${ }^{12}$. Xa que logo, calquera gromo dun inxenuo optimismo pedagóxico está por completo ausente, prevención avalada polos moi deficientes resultados que se obtiveran coas experiencias levadas adiante ata o de agora, todas elas obxecto dunha severa e sistemática crítica na Memoria e mais no Informe. Como reacción fronte do teoricismo dominante ata entón, a aposta de Pallares é cara un ensino de carácter eminentemente práctico que tería nas granxas-modelo (unha por provincia) a súa concreción institucional. Daquí sairían individuos con formación dabondo como para dirixir a súa propia explotación ou ben empregarse como capataces nas de terceiros, agardándose que por un efecto de mímese o seu xeito de traba-

\footnotetext{
${ }^{12}$ Para o tema do ensino agrícola na España do s. XIX, Calatayud Giner (1987) e as páxinas que lle adica Fernández Prieto (1998, pp. 242-253).
}

"CUADERNOS DE ESTUDIOS GALLEGOS", Tomo XLVII, Fascículo 112, Santiago 2000. 
llar (avalado na previsible obtención de máis e mellores colleitas) fose logo imitado polos restantes cultivadores. En definitiva, o que se estaba a ofrecer era unha simple versión, modificada na forma pero non tanto no fondo, do clásico exemplarismo ilustrado baseado no erroneo principio de crer que o éxito duns poucos é dabondo para convencer á maioría de que abandone os seus tradicionais e obsoletos métodos de traballo, unha idea que non ten en conta nin os custos (humanos e materiais) que pode supoñer o cambio nin as posibilidades reais dos colectivos afectados para levar adiante esa variación (Boserup, 1967).

É claro, xa que logo, que a estensión do ensino agrícola non representa ningún tipo de panacea en tanto se manteñan os atrancos estructurais que son os que realmente precisan dunha solución urxente, polo que a modificación das condicións que rexen a propiedade en Galicia é o primeiro e imprescindible paso a dar, "que por muy pronto que sea será bien tarde» (Informe, p. 116). A superación de todas estas eivas sería a que permitiría desenvolver as potencialidades do sector chamado a liderar o demarrage agrícola galego, responsabilidade que o Conde (como a maioría dos pensadores do momento) outorgaba á gandería bovina ${ }^{13}$. A elección axeitábase ben tanto á realidade do país (que tiña na exportación do vacún unha importante fonte de ingresos) como á liña de actuación que seguía a agricultura máis avanzada do momento, a inglesa, polo que cando menos na teoría a centralización dos esforzos a prol da promoción gandeira era unha decisión atinada, máxime cando no pensamento pallaresco calquera tentación maximizadora ou arbitrista aparecía freada por un saudable e prudente realismo ${ }^{14}$. Así, entendía que os cruces para mellorar a calidade dos

\footnotetext{
${ }^{13}$ Sobre o tema, Fernández Prieto (1996), Carmona (1982).

${ }^{14} \mathrm{O}$ realismo faise igualmente presente noutros aspectos do pensamento pallaresco, por exemplo ao defender unha introducción pausada e con moito tino de calquera novidade que supuña un cambio nos métodos tradicionais de traballo, variacións so aceptables logo de adaptadas ás especiais características e necesidades do agro galego. Así, dí na Memoria en que glosa a exposición agrícola lucense de 1867: "Cuando se trata de cambiar un sistema de cultivo, por muy atrasado y rutinario que sea, es preciso primero mucha prudencia y después mucha constancia [siendo la rutina] menos temible que los adeptos irreflexivos que acogen con entusiasmo brillantes teorías, poco meditadas a veces y otras de aplicación dificil». O mesmo afirma verbo da mecanización, por canto nas leiras galegas non poden funcionar «ni las grandes máquinas movidas por el vapor ni muchas de las que exigen la fuerza animal».
}

"CUADERNOS DE ESTUDIOS GALLEGOS", Tomo XLVII, Fascículo 112, Santiago 2000. 
animais deberían efectuarse con exemplares autóctonos antes que con razas estranxeiras, dotadas de certo dunhas excelentes cualidades pero demandantes dun nivel de alimentación, cuidados e estabulación imposibles de ofrecer en Galicia, do mesmo xeito que habería que esquecer a moi lucrativa especialización británica para continuar apostando por un gando de aptitude mixta (traballo, carne e leite), sen dúbida o que mellor respostaba ás necesidades e posibilidades de mantenza das explotacións agrarias galaicas. En directa correspondencia e actuando nun sentido complementario con esta aposta polo bovino, está a proposición do Conde tendente ao establecemento de completas rotacións de cultivos, que ademais de superar o barbeito permitirían dar entrada ás forraxeiras e leguminosas imprescindibles na alimentación do gando. Son, como se comproba, alternativas interesantes, feitas con tino e con coñecemento das limitacións/necesidades do país, pero que frouxean claramente no sentido de que a carón das posibles solucións nunca atopan concreción os medios (institucionais, lexislativos, financieiros) con que facelas efectivas, de tal xeito que as propostas, fallas tanto de apoios oficiais como de respaldo social efectivo (que só se acadará co societarismo agrario a comezos do s. $\mathrm{XX}$ ), quedarán inutilizadas e paralizadas no xa rebordante universo das boas intencións.

Pallares participa da indefinición e das ambigüidades en canto ao suxeito da innovación que son características dos arbitristas agrarios da Galicia decimonónica (Fernández Prieto, 1992, pp. 71 e ss.). Como rendista que é, resístese a conceder todo o protagonismo na renovación agrícola aos cultivadores da terra marxinando aos mal chamados propietarios (que en Galicia o son case só do directo), mais ao tempo o seu realismo e o seu contacto directo co cultivo (noutro lugar témolo definido como «experimentador de horta»: Veiga, 1998, p. 40) obrígano a situar nos labregos un papel certamente máis importante que o outorgado por outros pensadores coetáneos, circunstancia visible tanto no seu apoio á redención foral como na súa teimosía en facer pasar pola proba da pequena explotación calquera innovación que se busque introducir. Un outro aspecto a salientar na faceta agraria do Conde céntrase no seu papel como organizador de exposicións agrarias e como lexislador foral, un activismo que o fai sobresaír dentro da foto de grupo que inclúe aos membros da chamada agricultura letrada. Así, participa na organización das exposicións lucenses de 1867 
e $1877^{15}$ (nesta última como presidente da comisión organizadora) tentando deste xeito outorgar algún tipo de saída práctica ás súas inquedanzas teóricas, reunións que comparten coas restantes do Estado tanto as súas ambiciosas metas teóricas (escaparates de cultivos, fomentadoras da producción pola vía da emulación, divulgadoras de novas técnicas e novos métodos, lugares de encontro entre productores e consumidores...) como os seus máis modestos resultados prácticos, de certo derivados do interese máis político-social ca económico dominante nestes concursos (Veiga, 1997, 1999a). Por último, e para rematar xa con estas páxinas adicadas ao pensamento e o activismo pallaresco no eido agrario, non podemos obviar o seu desempeño como lexislador foral que supón a culminación dunha preocupación polo tema que sitúa as súas orixes nas páxinas do Correo (1860-61), continúa nas reflexións en sentido redencionista que publica en La Época (1866) e na campaña contra a lei de redención republicana en El Eco de Galicia (1872-74), para atopar por fin a culminación no seu papel como secretario-poñente no proxecto de lei de redención foral presentado (e aprobado) no Senado en 1878, pero que finalmente non pasará a proba da Cámara Baixa. Unha traxectoria, contra do que en principio poida semellar pola actuación nos anos da I República, dotada de grande coherencia interna e propia dun individuo que dende moi cedo entendeu a cesión foral como un dos principais atrancos a superar no establecemento dunha agricultura capitalista, pero que ao tempo nunca puido obviar nin as súas orixes de clase nin a súa posición como fidalgo rendista que o obrigaban a buscar unha saída ao atoalleiro do foro menos gravosa para os directos que a representada pola lei de 1873. A proposta redencionista de 1878 (tipo do $4 \%$ para os foros e do $5 \%$ para os subforos), finalmente non concretada, era a alternativa que a mente de Pallares entendía como máis aceptable para tentar irmandar no posible o interese xeral do país co particular dos perceptores forais.

Mantendo un vencello directo cos plantexamentos de reforma agraria está a cuestión do ferrocarril, dúas estradas paralelas que na Galicia do s. XIX (ao igual ca no resto do Estado) se presentan como as metáforas por

${ }^{15}$ Ver, «La Exposición Agrícola y de Ganados celebrada en Lugo. Octubre de 1867» e «La Exposición Regional de Lugo en 1877 y documentos diversos». Os dous fondos conservados no MPL. 
excelencia do progreso e as vías de obrigado tránsito para instalar definitivamente ao país no camiño da modernidade europea. Xa temos visto como nas páxinas de El Correo de Lugo o conde de Pallares explicitara a estreita conexión existente entre a consecución do tren e a realización de transformacións no eido agrario, de tal xeito que só unha vez feitas estas poderían os camiños de ferro exercer o seu beneficioso influxo permitindo a rápida e cómoda distribución da producción agrogandeira galega, ao tempo que só contando con un incremento considerable desta estaría a vía férrea en condicións de proporcionar unha explotación beneficiosa. A complementariedade dos dous proxectos era tal que mesmo non faltaban voces indicando o prexudicial que resultaría a chegada do ferrocarril se non ía acompañada de variacións na estructura da propiedade, por canto a producción galega quedaría aberta á competencia exterior sen, á súa vez, estar en condicións de competir nos mercados estatais. Non obstante isto, eran tais as esperanzas que espertaba o ferrocarril, así como o medo a quedar sen el, que toda análise fría e desapaixoada da situación estaba condeada ao fracaso, de tal xeito que o logro da vía férrea logo pasou de ser un simple proxecto económico a convertirse na teima colectiva por excelencia do país e na auténtica proba de forza dos seus anceios de modernidade e das súas posibilidades de desenvolvemento inmediato. En resumo, o tren convertíase na versión contemporánea do clásico corno da abundancia ${ }^{16}$.

Pallares, aínda que situado a prudente distancia dos seus compañeiros ferroviarios máis entusiastas, participa plenamente do ambiente de euforia que se respira na Galicia de finais de 1850 verbo das posibilidades de mellora material que introducirá o camiño de ferro. Tal é así que na súa primeira experiencia como parlamentario, no bienio $1857-58$, a consecución dunha vía férrea que engarce Galicia coa Meseta convértese no proxecto por excelencia a defender nas Cortes, idea na que fan causa común a

${ }^{16}$ « ¿Cuál será el resultado inmenso de la construcción del camino de hierro de Galicia? El movimiento de sus puertos, la construcción de otros ramales, y de caminos comunes, la vida de su agricultura, la roturación de terrenos, el establecimiento de fábricas, y nuevos cultivos, la creciente, hoy increible prosperidad de Galicia, y por consiguiente la utilidad y bien general de toda la península» (N. Pardo Pimentel, «FerroCarril de Galicia», El Correo de Lugo, 20-V-1860). Sobre o mesianismo ferroviario deses anos, Barreiro Fernández (1986).

"CUADERNOS DE ESTUDIOS GALLEGOS", Tomo XLVII, Fascículo 112, Santiago 2000. 
totalidade dos deputados galegos xunto cos representantes das provincias non galegas interesadas na liña (en concreto, Palencia, León e Oviedo). Froito desta colaboración é a publicación da lei 21 de abril de 1858 pola que o executivo dá o visto bo a unha liña que una Palencia con A Coruña, lei que tiña o seu antecedente inmediato nunha proposición presentada ao goberno por unha comisión de deputados na que Pallares figuraba como secretario (Diario de Sesiones de las Cortes. Congreso de los Diputados: no sucesivo, DSC.CD, 26-IV-1858, apéndice $4^{\circ}$; Gaceta de Madrid, ${ }^{\circ}$ 118, 28-IV-1858). A partires deste momento, a relación entre o noso biografiado e o bautizado como Ferro-Carril del Príncipe Don Alfonso vai a ser constante, ata o punto que sen caer en esaxeración algunha pódese afirmar que o Conde está presente en todos e cada un dos fitos claves que definen o longo e traballoso camiño que, dende a súa xestación lexislativa, sigue a vía férrea ata facerse realidade.

Unha primeira subhasta da totalidade das seccións da liña ten xa lugar en febreiro de 1859, mais ningún licitador acode a ela: as esixencias financieiras dunha obra de tamaña envergadura, xunto da baixa subvención ofrecida polo goberno ( $38 \%$ do presuposto), serían algunhas das razóns que explican a incomparecencia. Este primeiro fracaso, lonxe de desanimar aos promotores da vía, dalles novos folgos para tentar de novo a súa licitación, mais agora adoptando as medidas oportunas para evitar un novo fiasco. Será o ferrolán Juan Flórez (deputado a Cortes pola Coruña en 1857-58 e un dos patrocinadores da lei de abril) quen xogue un papel máis salientable neste novo intento, tendo no conde de Pallares ao seu máis incondicional apoio na provincia lucense. A idea de Flórez verbo do ferrocarril é moi clara: antes de solicitar unha nova subhasta, e de arriscarse a repetir o ocorrido coa anterior, hai que ter claros os apoios con que conta o proxecto no país, e para iso nada mellor que realizar unha suscrición pública de accións con destino á proxectada liña férrea. Coa erección de xuntas de suscrición por todo o país (ver, MPL: fondo «Documentos sobre el ferrocarril de Galicia»), Flórez comeza a dar forma ao seu proxecto, ben acompañado por un Pallares que se erixe no animador da xunta lucense ao tempo que, como xa vimos, patrocina a fundación de $E l$ Correo de Lugo como voceiro encargado de publicitar e dar a coñecer cantas novas xurdan arredor do proxectado ferrocarril. Porén, e a pesares dos esforzos despregados e dos substanciais apoios recibidos (Saurín de la Iglesia, 1977, pp. 208 e ss.), a suscrición en Lugo (menos de 7 millóns de rs.) non enche 
en absoluto as previsións de Flórez e Pallares quenes calcularan situar en toda Galicia accións por valor de 80 millóns de rs. A análise polo miúdo do proceso de toma de títulos en Lugo amosa a enorme febleza e o desinterese do capital privado por participar no negocio, por canto unicamente se fai co $24 \%$ das accións, en tanto que todas as restantes resultan suscritas por organismos públicos (deputación e concellos). De feito, nin sequera a totalidade dos municipios da provincia participa na adquisición por canto o $39 \%$ rexeitan facelo (moi en especial aqueles máis afastados do percorrido da vía), proba evidente de que nin a nivel oficial a idea do ferrocarril atopara unha acollida unánime. Semellaba claro que a composición da sociedade lucense, tanto pola súa estructura dominada por unha fidalguía rendista nada interesada na vía férrea segundo se desprende da súa escasa presencia entre os compradores de accións (Veiga, 1995-96a), como pola mínima representación con que conta de grupos burgueses, non era a máis axeitada para dar resposta a un investimento cento por cento capitalista como era o do ferrocarril.

Os deficientes resultados obtidos na suscrición impiden que Flórez poida solicitar a saída a subhasta de todo o camiño, polo que finalmente son só os tramos castellanos de máis doada e barata construcción (Palencia-León e León-Ponferrada) os que se licitan (febreiro de 1861), resultando gañadora na puxa a compañía «Miranda e Hijo» logo de ofrecer unha rebaixa na subvención oficial de nada menos que o $23 \%$ (case 18 millóns de rs.). Para Galicia este resultado resultaba dobremente prexudicial por canto non só quedaba sen ferrocarril senón que, a maiores, a liña víase privada das atractivas (polo seu doado levantamento) seccións castellanas: ¿que constructor ousaría agora acometer o tendido pola crebada orografía galega sen contar coa compensación da chaira castellana? (Revista Económica de Santiago, 1860-61, pp. 22-24). Sen embargo, e a pesares disto, a finais de 1862 recíbese en Galicia unha curiosa oferta de construcción por parte do marqués de Salamanca, de certo un dos máis coñecidos especuladores da época. Salamanca ofrecíase como constructor sempre e cando se lle permitise variar as condicións técnicas do tendido (maiores pendentes e curvas de menor radio), proposición que finalmente é desestimada por considerarse, atinadamente, que faría case imposible a posterior explotación do ferrocarril (Revista Económica de Santiago, 30-XI, 30-XII-1862 e 15-I-1863). Con posterioridade, e diante da falla de ofertas, é a deputación de A Coruña quen decide tomar a inicia- 
tiva a comezos de 1863 , e así acorda contratar un empréstito por valor de 60 millóns de rs. co que financiar a construcción da vía, proxecto ao que rapidamente se engade a deputación de Lugo (Actas da Deputación de Lugo, 8 e 9-III-1863; La Ilustración de La Coruña, 28-I-1864). Pero tampouco esta alternativa, fronte da que Pallares amosa non poucas reticencias pola enorme carga financieira que suporía para as provincias, acada concreción práctica algunha ${ }^{17}$.

A estas alturas, a análise que os promotores do camiño de ferro galego facían da situación chegara a unha clara conclusión: o desinterese que pola liña tiñan os posibles constructores derivábase do mantemento duns presupostos obsoletos e excesivamente baixos (foran calculados en 1857), dos que se derivaba unha subvención gobernamental igualmente cativa en termos absolutos. Xa que logo, a solución era arrincar do ministerio de Fomento un compromiso polo que os presupostos fosen reformados á alza, laboura á que se adican nos días finais de 1863 tanto Pallares como os seus compañeiros de representación parlamentaria ${ }^{18}$. Logo dunha nova subhasta realizada o 25 de abril de 1864 á que, de novo, non se presenta ningún constructor, faise evidente que a solución pasa sen remedio polo incremento dos presupostos, que finalmente lógrase coa lei 9-VI-1864 (DSC.CD, 17 e 20-V-1864 e 9-VI-1864, apéndice 10). Co aval dos novos presupostos que superan os 400 millóns de rs., e unha subvención de algo máis de 200, os tramos entre Ponferrada eA Coruña saen unha vez máis a puxa pública o 19 de setembro de 1864, facéndose con eles José Ruiz de Quevedo ofrecendo unha rebaixa na subvención do goberno de nada menos que 42 millóns de rs., pasando esta dos 202 orixinais aos 160 en que queda fixada (Gaceta de Madrid, 27-IX-1864). De inmediato, e nunha operación cento por cento especulativa, cede os dereitos das liñas á «Miranda e Hijo», a constructora que dende 1861 viña levantando as seccións castellanas do camiño, constituíndose agora unha nova empresa que toma o nome de «Cia. de los Ferro-Carriles de Palencia a La Coruña y de León

${ }^{17}$ Carta de B. Rebellón a Pallares (sen data): AHPL, CP, leg. 9, correspondencia de 1863.

${ }^{18}$ O Conde, xunto de Benito Plá Cancela, Antonio Romero Ortiz, Frutos Saavedra Meneses, Augusto Ulloa, Constantino de Ardanaz e Alejandro de Castro, reúnense con Alonso Martínez (titular de Fomento) en decembro de 1863 para solicitarlle dita reforma. Ver, papel solto conservado no AHPL, CP, leg. 9. Tamén, DSC.CD, 25-I-1864, p. 817. 
a Gijón, o del Noroeste de España».A cesión, como é doado supoñer, non resulta gratuíta, por canto Quevedo mantense como constructor óbtendo un substancial aumento dos presupostos que se ven inflados en nada menos que 190 millóns de rs., enorme carga económica que asume a nova compañía e grande beneficio para un Quevedo quen en a penas uns días vía compensado o seu investimento dun xeito espectacular ${ }^{19}$. O ferrocarril debía estar rematado en setembro de 1869.

A partires deste instante a historia da liña galega convértese nunha sucesión continua de prórrogas e aprazamentos resultado tanto da manifesta incapacidade financieira da constructora para levar adiante as obras, como dun emprego inaxeitado das subvencións outorgadas polo goberno e dunha actuación pouco firme deste diante da actitude da Cia. do Noroeste. A primeira das prórrogas dilata o previsto remate dos traballos ata novembro de 1873; con posterioridade, e diante da evidencia de que tampouco agora a vía estaría concluída, a compañía obtén un segundo aprazamento que fixa a finalización en decembro de 1876, e mesmo a concesionaria chegará a gozar dunha terceira prórroga (aínda que de só seis meses) pola lei do 12-I-1877, regulamento que marca un cambio de rumbo absoluto na historia da Palencia-A Coruña pois a aplicación dos seus contidos conlevará a incautación do ferrocarril polo Estado nunha decisión coido que sen precedentes na historia ferroviaria española do s. XIX. O que a nós agora nos interesa é que, para chegar a esta saída, a intervención do conde de Pallares resultou fundamental ao figurar como presidente da comisión que no verán de 1876 dictaminou favorablemente a solución da incautación (DSC.CD, 8 e 22-VI-1876, apéndices sexto e octavo, respectivamente). En realidade, o seu seguemento do tema arrinca de máis atrás, en concreto da lexislatura de 1871 cando solicita no Congreso un informe sobre o estado das obras para de seguido, e na compaña doutros deputados lucenses e coruñeses, esixir do executivo unha declaración na que se obrigue á compañía a axilizar o ritmo dunhas obras que marchaban a paso de tartaruga (DSC.CD, 22-V e 7-VII-1871) ${ }^{20}$. Tamén dende o seu

\footnotetext{
${ }^{19}$ Todos os detalles, en Plácido Jove y Hevia, Dictamen del diputado ponente acerca de los ferro-carriles de Palencia a La Coruña y de León a Gijón, o del Noroeste de España», conservado no MPL, fondo «Impresos y manuscritos de carácter político y literario».
}

"CUADERNOS DE ESTUdIOS GALLEGOS", Tomo XLVII, Fascículo 112, Santiago 2000. 
xornal El Eco de Galicia se ocupará do tema, manifestando unha actitude cada vez máis claramente contraria á constructora adiantando o que será a súa futura postura favorable á incautación («La empresa del ferro-carril», 24-III-1874; «Un recuerdo», 30-V-1874). Pero será xa coa Restauración cumprida cando de novo Pallares recupere un posto de primeira liña na loita férrea, en concreto na súa calidade de presidente da comisión encargada de aportar algún tipo de saída ao complexo culebrón en que a estas alturas se tiña convertido a construcción do ferrocarril galego.

Das conclusións desta comisión tíranse algúns datos importantes que axudan a comprender os porqués da parálise que afectaba aos traballos do ferrocarril. En primeiro lugar, o calamitoso estado económico da constructora que sitúa a súas orixes en diferentes fontes: as enormes rebaixas feitas nas subvencións gobernamentais co obxecto de vencer nas subhastas (18 millóns de rs. nos tramos Palencia-León e León-Ponferrada; 42 millóns nas seccións de Ponferrada-A Coruña; 5 millóns na de León-Gijón), os deficientes resultados obtidos na saída a bolsa das accións e obrigacións do camiño, lóxicos se temos en conta que a operación coincide coa grave crise financieira de 1866 (Gaceta de Madrid, 9-IV-1874; DSC.CD, 8-VI-1876, apéndice sexto), e os xogos especulativos que xurden arredor das liñas que teñen o seu exemplo máis espectacular na onerosa cesión (xa vista) das seccións Ponferrada-A Coruña por parte de Ruiz de Quevedo á «Miranda e Hijo», dende 1861 concesionaria dos tramos Palencia-Ponferrada. En segundo lugar, hai que facer referencia á fraudulenta cobranza e ao desviado emprego que a constructora fai das cuantiosas subvencións outorgadas polo goberno. No «Dictamen de la comisión relativo al examen del expediente del ferro-carril del Noroeste de España» (DSC.CD, 8-VI-1876, apéndice sexto), afírmase literalmente:

${ }^{20} \mathrm{O}$ Conde dispuña de informacións de primeira man que acusaban á constructora de todo tipo de irregularidades: cobro ilegal de subvencións, importación fraudulenta de material do estranxeiro, deputados que actúan protexendo seus intereses... Ver, cartas de Venancio de Abella e duns autotitulados «Trabajadores de la compañia del Noroeste» a Pallares, 31-V e ?-VI-1871: MPL, fondo «Documentos sobre el ferrocarril de Galicia». Tamén a prensa acusaba a Noroeste do cobro irregular de axudas gobernamentais: $E l$ Avisador, 15-VII-1871. Do mesmo xeito, as deputacións comezaban a esgotar a súa paciencia coa constructora, e así en maio de 1871 as de Lugo e A Coruña esixían do goberno a adopción de medidas para fiscalizar as súas actividades e solicitaban a non concesión de novas prórrogas. 
"(...) la compañía, cobrando los trozos de menor coste por el sistema de grupos de a cuatro kilómetros concluidos, y los costosos por el sistema de relaciones valoradas de obras ejecutadas mensuälmente, ha llegado a percibir en alguna época y en casos determinados (...) sumas que dan un 110 por 100 recibido en relación a lo gastado».

Deste xeito resulta comprensible que a finais de 1876, e restando por construír os tramos de maior custo entre Ponferrada e Sarria, a subvención esté xa consumida nun $72 \%$. Simplemente porque a compañía, aproveitando os valeiros legais da norma regulamentadora do pago dos auxilios, lograra efectuar os cobros sen ter feito os traballos correspondentes, ata o punto que se pode afirmar que a práctica totalidade do construído se fixera investindo unicamente capitais procedentes das subvencións oficiais sen que a constructora aportase practicamente nada de fondos propios (Veiga, 1999d, p. 276). Por último, non debemos esquecer a responsabilidade dos sucesivos gobernos en todo este asunto, clave cando menos en dous aspectos: por unha banda, na fixación dun sistema de concesión das liñas guiado exclusivamente por criterios economicistas, de tal xeito que nas subhastas vencían as proposicións que ofrecían maior rebaixa na subvención oficial sen que se tivese en conta ningún outro aspecto, feito que propiciaba a puxa por parte de empresas máis interesadas nos xogos especulativos que as concesións permitían (o caso de Ruiz de Quevedo) que na propia construcción e posterior explotación do ferrocarril. Pola outra, na incapacidade para adoptar medidas drásticas e a tempo fronte da Cia. do Noroeste, preferíndose pola contra manter unha actitude contemporizadora que non fixo máis que aprazar e agudizar o problema, un posicionamento que ten moito que ver tanto coas interferencias entre política e negocios como coa incapacidade das arcas estatais para garantir a continuidade das obras unha vez rescindida a contrata á constructora ${ }^{21}$.

${ }^{21} \mathrm{O}$ exemplo máis evidente desta interferencia é sen dúbida o que protagoniza o deputado por Sarria Leocadio Cacho nas Cortes de 1873, cando figurando como asalariado da Cia. do Noroeste non dubida en presentar unha proposición no seu favor solicitando a concesión dunha prórroga para o remate das obras. Ver, DSC. CD, 19 e 20-IX-1875. Verbo do temor a un parón total das obras unha vez consumada a rescisión, $D S C$. $C D$, 19IX-1873, p. 2.428.

"CUADERNOS DE ESTUDiOS GALLEGOS", Tomo XLVII, Fascículo 112, Santiago 2000. 
A medida a adoptar que a comisión dirixida por Pallares propón para solucionar o tema do ferrocarril é tan drástica como espectacular: conceder un prazo á constructora para realizar traballos por valor de 4 millóns de pts (en concreto, seis meses) e, no caso de non poder cumprir con esta condición, proceder á inmediata nacionalización das vías que dende ese instante pasarían a ser propiedade do Estado. Tomando como base esta proposición publícase a lei 12-I-1877, que finalmente será a que dé cobertura legal á incautación das liñas que ten efecto en febreiro de 1878. En xusta correspondencia cos seus desvelos, o papel do Conde nesta inédita solución era recoñecido de xeito unánime (Diario de Lugo, 2-II-1877). A partires daquí, e co seu acceso á senaduría vitalicia, o protagonismo do noso biografiado no eido férreo, tan evidente ata o de agora, practicamente desaparece polo que non terá intervención algunha nos sucesivos avatares que segue a liña galega ata facerse realidade en 1883 (moi en especial, a súa reprivatización en 1880), mais de xustiza é recoñecer na súa figura a un dos principais animadores da loita ferroviaria que por espacio de 25 anos tivo como escenario a vía Palencia-A Coruña.

\section{NA BUSCA DO PODER: POLÍTICA E CLIENTELISMO}

En febreiro de 1832 morría o pai de Manuel, D. Antonio Vázquez de Parga. Deixaba unha viúva ( $D^{a}$ Manuela) e tres fillos: Manuela de 10 anos, $\mathrm{M}^{\mathrm{a}}$ Josefa de 8 e o propio Manuel de 4 . Deste xeito o futuro conde quedaba como único herdeiro varón e, xa que logo, correspondíalle asumir o máis rapidamente posible as funcións que lle eran propias, destinado como estaba a perpetuar o apelido, defender o bo nome da casa, protexer o patrimonio e seguir o ronsel deixado polo seu pai. $\mathrm{O}$ feito de quedar tan cedo sen a figura paterna, convirte ao xove Manuel nun adulto prematuro obrigado a exercer como tal e a respostar con prontitude aos desafíos que lle impón a súa condición social fidalga e a súa pertenza ás clases dirixentes do país. Algunhas mostras desta forzada precocidade xa as temos visto (a dirección da Revista de Galicia sen ter aínda cumpridos os 22 anos ou o casamento con a penas 23), mais é no eido da política onde se manifesta con maior claridade. Seu pai D. Antonio, ademais de figurar como importante funcionario de Facenda con Fernando VII (subdelegado de rendas da provincia de Lugo), tivera unha curta pero intensa actividade parla- 
mentaria como integrante da representación lucense nas cortes de Cádiz entre 1810 e 1813. Este feito vai marcar decisivamente a vida de Manuel, que se vai a ver pouco menos que predestinado á vida pública para deste xeito continuar cun papel que o seu proxenitor tiña representado anos atrás. Así, xa na súa etapa como universitario en Salamanca lle lembraban dende Lugo cales eran as súas obrigas:

«Salud le deseo, y progresos literarios, sin olvidar los espirituales, con lo que podrán contar los Srs. de Lugo mañana con un Sr. Diputado que ayude y sostenga sus derechos, sin necesidad de acudir a forasteros, que no hacen más que engrandecerse a costa de los comitentes, y esto si no es, como ya tiene sucedido, en perjuicio de ellos $\rangle^{22}$

O biografiado resposta con prontitude a estas demandas, participando como aspirante moderado a Cortes polo distrito de Lugo nas eleccións de febreiro de 1853 sen ter aínda cumpridos os 25 anos que para ser candidato fixaba a lei electoral ${ }^{23}$. Este primeiro intento resulta un completo fracaso, mais non por iso esquece Manuel un obxectivo que de novo tenta acadar nas eleccións de 1854 colleitando unha nova derrota, repetindo a intentona un ano despois (tíñase producido unha vacante na representación lucense) con idéntico resultado ${ }^{24}$. Terá que agardar ata os comicios de marzo de 1857 para, por fin, resultar electo deputado polo distrito de Lugo capital, unha elección que se produce por unanimidade reflexando así o consenso acadado arredor da súa figura entre os poderes locais e o poder central ${ }^{25}$. O coñecido como «Goberno Largo» do xeneral O'Donnell (1858-1863) transcorre co xa conde de Pallares fóra do Parlamento, ao resultar derrotado nas eleccións de 1858 a mans do candidato gobernamental Ramón Neira Montenegro. Deste xeito, non é ata outubro de 1863 cando Pallares retoma o pulso parlamentario ao ser elexido deputado polo

\footnotetext{
${ }^{22}$ Carta de F. Noguerol a Manuel Vázquez de Parga (31-I-1847): MPL, fondo «Sr. Conde de Pallares».

${ }^{23}$ Ver, cartas de Vázquez de Parga a Luis de Trelles e viceversa (varias de 1853): AHPL, CP, leg. 9.

${ }^{24}$ AHPL, sección Concello, serie Eleccións, leg. 438. Tamén, B.O.P. de Lugo, 20VII- 1855.

${ }^{25}$ AHPL, sección Concello, serie Eleccións, leg. 439.
} 
distrito de Mondoñedo, retorno que de certo asume coa firme intención de recuperar o tempo perdido logo de cinco anos de obrigado ostracismo político. Porén, as cousas non marchan segundo a dirección prevista e problemas familiares obrígano a retirarse da vida política só un ano despois iniciando un voluntario exilio no seu pazo chairego de Penas Corbeiras, retraemento do que só sae en 1871 para presentarse nas eleccións provinciais como aspirante polo distrito de Trasparga, representación que obtén sen dificultades ${ }^{26}$. O paso polo pazo provincial da rúa de San Marcos resulta fugaz, por canto nese mesmo ano acada a representación en Cortes (como candidato moderado de oposición) polo distrito de Vilalba. Nas de agosto de 1872 repite o éxito do ano anterior (de novo como aspirante da oposición, aínda que agora xa baixo o rótulo de alfonsino), pero non sen antes sufrir nas súas propias carnes a dureza sagastina nos comicios de abril dese mesmo ano que incluíron 50 feridos e un morto entre os apoios vilalbeses do Conde (AHPL, CP, legs. 3 e 11). Finalmente, e xa co desexado Alfonso XII no trono, Pallares participa na súa derradeira campaña electoral que o leva ata as cadeiras do Congreso en 1876, para tan só un ano despois abandonar este posto por outro de senador vitalicio co que a reinstaurada monarquía premiaba os seus esforzos a prol da causa. Dende aquí, e practicamente ata fin de século, exercerá como xefe da agrupación conservadora lucense, ao tempo que figurará como o polo conservador na relación turnista que se establecerá na emblemática circunscripción da capital e que terá en Benigno Quiroga López-Ballesteros ao seu alter ego liberal.

Toda a actividade política de Pallares desenvólvese dentro do contexto clientelar que é característico do s. XIX español (Moreno Luzón, 1995; Zurita, 1994; Veiga, 1999b). Ideoloxicamente intégrase na corrente do moderantismo histórico que é a claramente dominante na maioría dos gobernos que se van sucedendo ao longo da centuria, presentando como única variación a salientar a súa precoz presentación alfonsina (xa en xullo de 1870 se amosaba convencido de que a bandeira boa a seguir era a

${ }^{26}$ Os problemas familiares fan referencia á sua esposa, $\mathrm{M}^{\mathrm{a}}$ de la Paz de la Riva y Estévez, que en agosto de 1864 demanda ao Conde diante do xulgado «sobre reintegro de su dote y capital y otros particulares». Ver, protocolo notarial de Domingo Carballo y Cabo, 19-VIII-1864: AHPL, sección Protocolos notariais, libro 1.013, fs. 982-983.

"CUADERNOS DE ESTUDIOS GALLEGOS", Tomo XLVII, Fascículo 112, Santiago 2000. 
do príncipe Alfonso) $)^{27}$ que o levará a afastarse rapidamente dos moderados morriñentos de Isabel II e da Constitución de 1845, para apostar por Alfonso XII e o proxecto canovista estructurado arredor do novo texto constitucional de 1876 . Se algún termo pode definir con exactitude o papel político xogado polo Conde dende que en 1857 acada a súa primeira representación en Cortes, ese é o de intermediario. E isto porque a principal das súas tarefas como deputado vai a ser en todo momento a de poñer en contacto o centro madrileño coa afastada periferia lucense, buscando un consenso (non sempre doado de acadar) entre os intereses dos poderosos locais firmemente asentados nos seus espacios cercanos de poder e aqueloutros que teñen a súa orixe na cerna do sistema. Xa que logo, o éxito político do Conde deriva da súa habelencia para moverse entre estes dous mundos sendo quen de manter aliados e apoios fieis tanto nunha beira como noutra. $\mathrm{O}$ que ofrece aos grandi elettori locais son as súas boas relacións madrileñas que garanten o reparto de beneficios e prebendas (basicamente orixinados naAdministración) entre as súas respectivas clientelas, en tanto que a súa forza en Madrid baséase nos múltiples contactos e clientes de que dispón na provincia lucense, fonte certa de apoio político-electoral para o goberno de turno. Neste sentido, Pallares aparece como o gardián dun pacto, altamente elitista, que se establece entre o centro e a periferia, un pacto que en absoluto implica ao conxunto da poboación senón só a aqueles que logran integrarse (porque teñen algo que ofrecer) dentro da clientela pallaresca. Estes son os que reciben un trato de favor pola banda daAdministración (empregos, traslados, sentencias favorables), en tanto que o resto da poboación (a inmensa maioría) é a que padece as consecuencias deste xeito arbitrario e fortemente discriminatorio de facer política.

Para as xeiras nas que está vixente o sufraxio censitario, este esquema clientelar baseado no intercambio de favores por apoio político, complementado coas posibilidades de intervención gobernamental nos procesos electorais, resulta dabondo para garantir a reproducción do sistema. Sen embargo, non debemos esquecer que tamén nestas etapas de voto restrinxido a variable económica resulta fundamental para o control político das poboacións, dende o momento que é un criterio cento por cento eco-

${ }^{27}$ Carta de Pallares a Calixto Varela (?-VI-1870): AHPL, CP, leg. 10. 
nómico o que marca a barreira entre os cidadáns electoralmente activos e os electoralmente pasivos. Se do que é este acceso limitado ao voto pasamos a un contexto dominado polo sufraxio universal, a importancia do factor económico faise explícita xa que agora a estratexia exclusivamente clientelar non é quen de asegurar os resultados apetecidos. A ampliación do número de votantes potenciais convirte ás eleccións, antes limitadas a unha cantidade reducida e doadamente controlable de participantes (que ademais compartían unha mesma condición elitista, fose polo seu poderío económico e/ou pola súa formación cultural), en actos potencialmente masivos nos que se dan cita electores de intereses moi heteroxéneos e que, xa que logo, para o seu control esixen da posta en marcha de mecanismos de carácter estructural que poidan influír neste electorado tan ampliado: a instrumentalización política da supremacía económica e, máis en concreto para o caso que agora nos ocupa, da posición dominante que dentro das relacións de producción ocupan os propietarios de terras e os perceptores de rendas que figuran como aliados políticos do Conde, pasa entón a desenvolver un papel absolutamente clave (AHPL, CP, leg. 10).

Fundamental para entender a actividade pública de Pallares é renunciar a comprendela a partires de criterios propios da segunda metade do $\mathrm{s}$. $\mathrm{XX}$, de tal xeito que xulgala atendendo a coordenadas ideolóxicas ou partidistas tentando identificar a existencia dun espacio propio e autonómo ocupado pola política, só levaría a un camiño sen saída. Ben ao contrario, é na estreita interdependencia entre relacións sociais e activismo político onde hai que situar as claves explicativas do seu quefacer, de tal xeito que lonxe de ocupar o político un territorio de seu aparece como unha prolongación case natural dos contactos sociais onde o papel que xogan familiares, parentes, amigos, veciños e coñecidos, en canto auxiliares do Conde na súa vida pública, resulta fundamental no seu éxito como mediador . Xa que logo, grande parte da súa sona como político sitúa os seus alicerces na capacidade que amosou para xerar consenso arredor da súa figura, obtendo crédito como xestor eficaz en Madrid das demandas do distrito (e viceversa) e gañándose a confianza dos seus clientes dentro dun contexto no que, como sinala o profesor Maiz (1997, p. 22), precisamente a desconfianza diante das institucións administrativas é a norma dominante. En todo momento Pallares aparece como o centro dunha rede clientelar que unicamente nos resulta ben coñecida nos seus compoñentes centrais, é 
dicir, naqueles individuos que manteñen unha relación máis estreita co biografiado e que a investigación teima en presentar como elementos dotados de poder, sexa este político, económico ou social cando non unha mestura desigual dos tres. Son estes os que forman o núcleo da pirámide clientelar que encabeza o Conde, xentes estratexicamente ubicadas nas diferentes vilas e aldeas que integran a circunscripción lucense e que á súa vez figuran como dirixentes de microclientelas locais, mantendo igualmente con elas unha relación de padroádego pero cunha importante e central diferencia verbo da fixada co conde de Pallares: mentras que a cesura socioeconómica existente entre Pallares e os seus clientes principais non é excesiva (polo xeral trátase de medianos e maiores contribuíntes que dispoñen dunha boa posición económica), a que existe entre estes e os integrantes das súas microclientelas (formadas a miúdo por dependentes agrarios) si tende a ser considerable, polo que en non poucos casos habería que falar máis dunha situación de dominio sen a penas contrapartidas para os dominados que non dunha conexión clientelar baseada no intercambio de servicios desiguais (Veiga, 1999c).

Todo o anterior lévanos a salientar, na liña en que o fai Estrada Sánchez (1999, pp. 119-120), o papel central que exercen os notables locais como axentes políticos do Conde, individuos básicos tanto na captación do apoio político-electoral como na realización de todos os traballos dirixidos a amañar o distrito nun sentido favorable ao seu patrón (confección das listas electorais, ocupación de cargos públicos nos concellos e xulgados, propaganda das xestións pallarescas a prol da circunscripción, organización das eleccións...). Do mesmo xeito, e en relación directa co que vimos de afirmar, hai que facer mención á importancia do nivel local dentro da estratexia política de Pallares, espacio local representado por estes poderosos de que falabamos aos que o deputado debe de coidar e alimentar cando menos con tanto esmero como ás conexións que mantén no centro do sistema, por canto só cunha plena adicación a cada un destes dous polos estará en condicións de asegurarse a súa cadeira nas Cortes e de manter o seu prestixio como mediador. Xa que logo, convén matizar moito as vellas teses costianas ao respecto da dirección descendente do poder que tendían a minusvalorar a importancia do local e a presentar ao Estado como o Leviatán que se impón en todos os recunchos do territorio, e isto porque nin a a estructura estatal é tan forte como se cría (Riquer i 
Permanyer, 1994; Fusi Aizpurúa, 1994) nin a periferia tan feble e desmobilizada como se supuña.

Xa para rematar, non podemos pasar por alto a análise da dinámica turnista que presenta a circunscripción lucense (integrada dende 1878 polos antigos distritos de Lugo capital, Vilalba e Sarria) ao longo do último cuarto do s. XIX, turno personificado no conde de Pallares pola banda conservadora e en Benigno Quiroga López-Ballesteros pola liberal-fusionista. Lonxe de aparecer como unha alternancia artificial e froito exclusivo das disposicións centralistas que se impoñen á periferia, preséntase como o resultado das negociacións entabladas entre dúas faccións locais, a pallarista e a ballesterista, que contan con sólidos apoios na circunscripción e que integran nas súas ringleiras a individuos de indubidable peso político e socioeconómico na zona, notables que son que de mobilizar (no sentido de ir votar ou de absterse, que as dúas son formas de participación política) a grupos de electores que manteñen con eles vencellos de carácter clientelar, deferencial ou de subordinación socioeconómica. Polo tanto, nin o turno é artificial pois representa dúas alternativas reais de poder existentes na circunscripción, nin ven definido dende Madrid por canto se forxa na propia periferia entre dous bandos que recoñecen mutuamente o seu poder e que, diante da doada constatación de que defenden iguais obxectivos centrados no acceso ao poder para dende el beneficiar aos seus integrantes, deciden turnarse pacificamente no seu disfrute obviando os riscos dunha posible derrota que sempre conleva a competición política non adulterada. Ata practicamente o 1900, e mentras Pallares e Quiroga foron quen de manter unidas as súas hostes e intactos os seus liderados sobre delas, o sistema funcionou á perfección sobre a base da elección de dous deputados do goberno por un da oposición dinástica (Veiga, 1999d, pp. 310-355).

Continuando coa idea da importancia e fortaleza do local nos procesos político-electorais decimonónicos, pódese aínda presentar unha última proba relacionada co perenne deputado conservador pola circunscripción lucense (exerce como tal dende 1881 ata a súa morte en 1899), o cuneiro Fernando Cos-Gayón. A historiografía ten tradicionalmente presentado ao cuneiro como a quintaesencia do intervencionismo gobernamental nos distritos, aos que lograba impoñer como representante a un individuo que, ata o día da votación, era un perfecto descoñecido para os electores. Unha análise superficial vería en Cos a este arquetipo, mais a realidade é por

"CUADERNOS DE ESTUDIOS GALLEGOS", Tomo XLVII, Fascículo 112, Santiago 2000. 
completo contraria. A clave explicativa desta aparente contradicción é moi simple: Cos é un cuneiro si, pero do conde de Pallares, pois foi este quen o promocionou como aspirante a Cortes por Lugo e quen, amparado nos seus contactos na circunscripción, o fixo deputado (AHPL, CP, leg. 18 bis; El Regional, 4-I-1891). Xa que logo, Cos-Gayón non representa ningunha proba do poder central e do seu control sobre dos espacios locais senón precisamente todo o contrario: é unha proba da autonomía e capacidade de decisión do poder local personificado no conde de Pallares. En canto ás razóns da súa escolla son tan simples como definitivas: en primeiro lugar, pola súa non presencia na circunscripción e a súa carencia de contactos directos nela, era un deputado cómodo para o Conde pois non entrañaba ningún risco de cara á continuidade indiscutida da súa hexemonía e, en segundo pero principal lugar, porque supuña o mellor dos auxiliares nas cotiás visitas de Pallares a ministerios e secretarías na busca de beneficios administrativos que repartir entre a súa clientela lucense. Non en balde, Cos exercerá en varias ocasións como ministro figurando sempre como un dos principais valores políticos do partido conservador. Definitivamente, a súa escolla fora un acerto pleno do conde de Pallares.

\section{BIBLIOGRAFÍA}

ABEL VILELA, A. de (1981): Cousas de Lugo, Lugo, AVA.

AGIRREAZKUENAGA, J. et al (1993): Diccionario Biográfico de los Parlamentarios de Vasconia (1808-1876), Vitoria-Gasteiz, Parlamento Vasco-Eusko Legebiltzara.

BAHAMONDE, A. \& MARTÍNEZ, J. A. (1994): Historia de España. Siglo XIX, Madrid, Cátedra.

BANTI, A. M. (1996): Storia della borghesia italiana. L'età liberale, Roma, Donzelli.

BARREIRO FERNÁNDEZ, X. R. (1986): «Debates ideolóxicos e políticos en Galicia no período 1846-1868», en VV.AA., Actas do Congreso 
Internacional de estudios sobre Rosalía de Castro e o seu tempo, Santiago de Compostela, Consello da Cultura Galega-Universidade de Santiago, pp. 355-370.

BERAMENDI, J. G. (1993): «Tres lustros para investigar dous séculos: un desenvolvemento desigual», Semata 5, pp. 243-273.

BOSERUP, E. (1967): Las condiciones del desarrollo en la agricultura, Madrid, Tecnos.

BOTREL, J-F. (1992): «La prensa en las provincias. Propuestas metodológicas para su estudio», Historia Contemporánea 8, pp. 193-214.

CALATAYUD GINER, S. (1987): «La difusión agrónoma en la segunda mitad del siglo XIX: a propósito de la enseñanza agrícola», Estudis d'història contemporània del País Valencià 6, pp. 165-194.

CARASA SOTO, P. (dir.) (1997): Élites castellanas de la Restauración. Una aproximación al poder político en Castilla, Salamanca, Junta de Castilla y León.

CARMONA BADÍA, J. (1982): «Sobre as orixes da orientación exportadora na producción bovina galega. As exportacións a Inglaterra na segunda metade do s. XIX», Grial 100, pp. 169-206.

CARRÉALDAO, U. (1991): A imprenta e a prensa en Galicia, A Coruña, Xunta de Galicia (reimpresión do orixinal).

CASANOVA, J. (1991): La historia social y los historiadores, Barcelona, Crítica.

CHAUSSINAND-NOGARET, G. (1986): «Biographique (Histoire)», en Burguière, A., Dictionnaire dès Sciences Historiques, Paris, PUF, pp. 86-87.

DOMÍNGUEZ CASTRO, L. \& QUINTANA GARRIDO, X. R. (1995): «Renovación na historiografía española:Antonio Eiras Roel e a recep-

"CUADERNOS DE ESTUDIOS GALLEGOS", Tomo XLVII, Fascículo 112, Santiago 2000. 
ción do movemento Annales en Galicia», en Barros, C. (ed.), Historia a Debate. Galicia, Santiago de Compostela, HAD, pp. 75-97.

DUBOIS, A. (1992): «La biographie dans l'histoire médiévale et moderne», en VV.AA., 17 Congreso Internacional de Ciencias Históricas, Madrid, Comité International des Sciences Historiques, pp. 1.093-1.104.

DURÁN DE LA RÚA, N. (1979): La Unión Liberal y la modernización de la España isabelina. Una convivencia frustrada, 1854-1868, Madrid, Akal.

ESTRADA SÁNCHEZ, M. (1999): La lucha por el poder: derecho de sufragio y fraude electoral (Liébana, 1834-1868), Santander, Parlamento de Cantabria-Ayuntamiento de Camaleño.

FERNÁNDEZ PRIETO, L. (1992): Labregos con ciencia. Estado, sociedade e innovación tecnolóxica na agricultura galega, 1850-1939, Vigo, Xerais.

- (1996): «Notas sobre a gandería de Galicia na segunda metade do século XIX», en Rodríguez Casal,A. (coord), Humánitas. Estudios en homenaxe ó Prof. Dr. Carlos Alonso del Real, Santiago de Compostela, Universidade de Santiago, pp. 697-723.

- (1998): «La política agraria del Estado español contemporáneo hasta 1936. Del propietario innovador al fomento de la innovación en la pequeña explotación», Historia Contemporánea 17, pp. 237-286.

FONTANA LÁZARO, J. (1973): Cambio económico y actitudes políticas en la España del siglo XIX, Barcelona, Ariel.

FUSI AIZPURÚA, J. P. (1994): «Centralismo y localismo: la formación del estado español», en Gortázar, G. (ed.), Nación y Estado en la España liberal, Madrid, Ed. Noesis, pp. 77-90.

LE GOFF, J. (1989): «Comment écrire une biographie historique aujourd'hui?», Le débat 54, pp. 48-53.

- (1995), «Le retours dans l'historiographie française actuelle», en Barros, C. (ed.), cit., pp. 157-165.

"CUADERNOS DE ESTUDIOS GALLEGOS", Tomo XLVII, Fascículo 112, Santiago 2000. 
LÓPEZ CORDÓN, Ma V. (1976): La revolución de 1868 y la I República, Madrid, Siglo XXI.

LORENZANA, S. (1988): «Breve historia da prensa periódica en Galicia», Grial 100, pp. 210-222.

MAIZ, R. (1997): «Desconfianza e poder persoal: os mecanismos elementais do clientelismo político», A Trabe de Ouro 31, pp. 13-31.

MCDONOGH, G. W. (1989): Las buenas familias de Barcelona. Historia social de poder en la era industrial, Barcelona, Omega.

MOLINA, C. A. (1989): Prensa literaria en Galicia (1809-1920), Vigo, Xerais.

MORADIELLOS, E. (1994): El oficio de historiador, Madrid, Siglo XXI.

MORALES MOYA, A. (1993): «Biografía y narración en la historiografía actual», en Montanari, M. et al, Problemas actuales de la historia, Salamanca, Universidad, pp. 229-257.

MORENO LUZÓN, J. (1995): «Teoría del clientelismo y estudio de la política caciquil», Revista de Estudios Políticos 89, pp. 191-224.

PEREYRA, C. (1984): El sujeto de la historia, Madrid, Alianza.

PÉREZ CONSTANTI, P. (1905): Historia del periodismo santiagués, Santiago de Compostela, Escuela Tipográfica Municipal.

PÉREZ PAIS, M ${ }^{\mathrm{a}}$ C. (1974?): voz «Prensa», en Gran Enciclopedia Gallega, t. 25, pp. 219-231.

PILLORGET, R. (1985): «La biografía, género histórico. Evolución reciente en Francia», en Vázquez de Prada, V. et al., La historiografía en Occidente desde 1945, Pamplona, EUNSA.

"CUADERNOS DE ESTUDIOS GALLEGOS", Tomo XLVII, Fascículo 112, Santiago 2000. 
PIQUERAS, J. A. (1992): La revolución democrática (1868-1874). Cuestión social, colonialismo y grupos de presión, Madrid, Ministerio de Trabajo.

- (1994): «De la biografía tradicional a la historia individual, grupal y masiva», en Carasa Soto, P. (ed.), Elites. Prosopografía contemporánea, Valladolid, Universidad de Valladolid, pp. 53-62.

RINGROSE, D. R. (1996): España, 1700-1900: el mito del fracaso, Madrid, Alianza.

RIOSA, A. (a cura di) (1983): Biografia e storiografia, Milano, Franco Angeli.

RIQUER I PERMANYER, B. de (1994): «La faiblesse du processus de construction nationale en Espagne au XIXème. siècle», Revue d'histoire moderne et contemporaine 41, pp. 353-366.

ROMANO, S. (1983): «Considerazioni sulla biografia storica», Storia della Storiografia 3, pp. 113-123.

ROMERO BALMAS, G-N. (1982a): «Criticismo y Economía Política en España bajo la Unión Liberal», Anuario de Historia Contemporánea 9, pp. 187-213.

- (1982b): «Liberalismo y desarrollo en España. Notas sobre el programa reformador a mediados del siglo XIX», Revista de Historia Contemporánea 1, pp. 227-240.

SAURÍN DE LA IGLESIA, Ma R. (1977): Apuntes y documentos para una historia de Galicia en el siglo XIX, A Coruña, Deputación.

SECO SERRANO, C. (1976): «La biografía como género histórico», en VV.AA., 11 ensayos sobre la historia, Madrid, Fundación Juan March, pp. 105-117.

SEOANE, $\mathrm{M}^{\mathrm{a}}$ C. (1983): Historia del periodismo en España, 2. El siglo $X I X$, Madrid, Alianza.

"CUADERNOS DE ESTUDIOS GALLEGOS", Tomo XLVII, Fascículo 112, Santiago 2000. 
SGAMBATI, V. (1995): «Le lusinghe della biografia», Studi storici 2, pp. 397-413.

SIEGRIST, H. (1989): «Gli avvocati e la borghesia. Germania, Svizzera e Italia nel XIX secolo», en Kocka, J. (a cura di), Borghesie europee dell'Ottocento, Venezia, Marsilio.

- (1992): «Gli avvocati nell'Italia del XIX secolo. Provenienza e matrimoni, titolo e prestigio», Meridiana 14, pp. 145-181.

STONE, L. (1982): «La historia como narrativa», Debats 4, pp. 92-105.

VEIGA ALONSO, X. R. (1995): «A biografía histórica do século XXI. Unha aproximación dende a práctica», en Barros, C. (ed.), cit., pp. 209-219.

- (1995-96b): «Individuo, sociedad e historia. Reflexiones sobre el retorno de la biografía», Studia Histórica. Historia Contemporánea 13-14, pp. 131-147.

- (1995-96a): «O conde de Pallares e o ferrocarril de Galicia», Boletín do Museo Provincial de Lugo VII, pp. 115-151.

- (1996): Progreso, prensa e ferrocarrís en Galicia. A Actividade do conde de Pallares (1858-1883), Lugo, Deputación.

- (1997): «Desarrollo agrícola y exposiciones. ¿Una relación causal?», Noticiario de Historia Agraria 14, pp. 165-192.

- (1998a): «La utopía ferroviaria de la Galicia decimonónica: la línea Palencia-A Coruña (1858-1883)», Congreso Internacional «150 años de ferrocarril en España», Alicante.

- (1998b): «Perfil do propietario innovador na Galicia do s. XIX. Historia dun desencontro», Documentos de traballo do IDEGA 6, pp. 1-53. - (1999b): «Anatomía del clientelismo político en la España liberal decimonónica: una realidad estructural», Hispania 202, pp. 555-579. - (1999d): O conde de Pallares e o seu tempo, 1828-1908. Aproximación ó activismo das elites na Galicia decimonónica, Lugo, Deputación-El Progreso.

- (1999a): «Exposicións lucenses no século XIX», Boletín do Museo Provincial de Lugo. VIII, pp. 115-151.

- (1999c): «Los marcos sociales del clientelismo político», Historia Social. 34, pp. 27-44.

"CUADERNOS DE ESTUdios GALLEGOS", Tomo XLVII, Fascículo 112, Santiago 2000. 
VILLANUEVA HERRERO, J. R. (1988): «Evolución y situación de conservación actual de la prensa turolense durante el siglo XIX», en VV.AA., La prensa española durante el siglo XIX. Ijornadas de especialistas en prensa regional y local, Almería, IEA, pp. 137-152.

VILLARES PAZ, R. (ed.) (1994): Congreso Agrícola Gallego de 1864, Sada (A Coruña), Ediciós do Castro.

ZURITA ALDEGUER, R. (1994): «La natura del potere politico nella Spagna della Restaurazione (1875-1902): un bilanzo storiografico», Quaderni storici 87, pp. 805-827. 